\title{
Local Governments as Nodes for Greenhouse Gas Abatement: Climate Change Governance in Multi- Level Frameworks
}

\author{
Magnus Franzén ${ }^{1}$
}

\begin{abstract}
:
This research concentrates on the governance aspects of sustainability, and more particularly how local governments can work as nodes in a wider system of governance. The question at the center of the study is: how do cities address climate change mitigation and how do their actions relate to other levels of governance? The study takes a mixed qualitative-quantitative approach based on a multi-level theoretical framework to address the issue. The study concentrates on a small number of cases and the material used is found in official documents and semi-structured interviews with key individuals in the local governments. The results of the study show that the cities investigated do take action to mitigate climate change; however, their actions are heavily dependent on other levels of governance, i.e. regional or national, or other actors. This dependence, nonetheless, seems to be reciprocal. Thus, cities can constitute nodes or hubs in the governance of climate change mitigation, working simultaneously as actors of implementation and channelizing local knowledge and input.
\end{abstract}

Keywords: Climate Change, Governance, Multi-Level, Sustainability, Local Governments

\section{Introduction}

Climate change has long been seen as an inherently global issue, but as international conferences and accords keep striking a wallof national interests and old fashion geopolitics, scholars from different disciplines have started to look beyond the international scale for an answer (Adger 2001; Bulkeley \& Betsill 2003; Dietz, Ostrom, \& Stern 2003; Kousky \& Schneider 2003; Biermann \& Dingwerth 2004; Rabe 2004; Granberg 2006; Rabe 2007; Janssen et al. 2008; Osofsky \& Levit 2008; Corfee-Morlot et al. 2009; Hochstetler \& Viola 2011). One geographical entity that has received considerable attention is cities. It is argued that in an increasingly urbanized world, the cities is where concrete action will have to take place, in order to curve escalating greenhouse gas emissions (Corfee-Morlot et al. 2009).

${ }^{1}$ Department of Economic History

Stockholm University / MFRC and Aumentare AB, Seeden 
However, the city is not an island, an isolated entity that exists in, and of, itself (Granberg 2004, p. 12). From a social, economic, ecological, jurisdictional, and political perspective, the city is a nested unit. It is part of increasingly global social processes to organize production (Lefebvre 1970, p. 2) and, certainly, consumption (Weber 1958 in Parker 2004, p. 10f). It is part of an economic web, where fluxes of capital and economic activity move from the local to the global level, and back again (Borja \& Castells 1997, p. 16f; Doucet 2007). It is part of an ecological system that do not respect borders or man-made frontiers, reaching from the regional eco-system around a lake or a sea, to the global biosphere where the basis of our existence, such as the atmosphere, is shared between all (Rees \& Wackernagel 1996; Borja \& Castells 1997, p. 128ff). It is part of a jurisdictional and political hierarchy and intermeshed system where decisions and power to change are sometimes dependent on the decisions of other institutions, related to the city vertically, as well as horizontally (Wilbanks \& Kates 1999; Bulkeley 2005; Granberg 2008).

This paper is an attempt to address the issue of scale when it comes to local action to mitigate climate change. Using a multi-level theoretical framework, two Swedish cities are studied as to how their actions to abate greenhouse gas emissions are connected to other levels of competence. The purpose is to discern to what extent local governments can proceed single-handedly with climate change mitigation and to what extent they need to work as part of a multi-level approach, coordinating with other levels of governance.

After this introduction, the paper continues with a theoretical discussion on the importance of levels in the analysis of local governance, as well as a brief description of the tools available for local government to govern climate change mitigation. The third section provides some comments on the sources, and the fourth section presents the results of the study. The paperconcludes with some final remarks.

\section{Theoretical Framework Theorizing on Scales and Levels}

The transcending nature of several issues in today's global society requires a framework that goes beyond the traditional state-centric approach adopted in international relations or the strictly local perspective that has received much attention in circuits of green political thought (Bulkeley \& Betsill 2003:10f, 18f). Several authors have pointed to the need for the inclusion of scales and levels in the analysis of local, as well as international governance (Rose 1973; Wilbanks and Kates 1999;Bulkeley 2005; Betsill and Bulkeley 2006; Ostrom 2010; Otto-Zimmermann 2011) 
Thus, instead of an approach that either focuses on the global level or on the local level, there is a need for a framework that takes into consideration the multi-level nature of local policy- making. Marks and Hooghe (2004) describe a conceptualization for multi-level governance. Dividing multi-level governance into two types, the authors try to create the basis for analyzing the division of decision-making between different levels in the EU (Hooghe \& Marks 2001; 2003). Four principle characteristics for each type can be identified. The first type, simply named Type $I$, refers to what can be best likened to a traditional federal system, where jurisdiction exist on a limited number of levels and contain several different functions. In addition, the jurisdictions do not overlap, rather are relevant only on each particular geographical scale to which they are bound. That is, just as can be seen in a federal system, jurisdictions are defined to a geographical space - municipality, state, federation - and each level contains a myriad of functions, such as local services, health care, environmental standards, infrastructure, military. Due to these characteristics, the Type I governance offer great stability and jurisdictions seldom change or cease to exist, if one function is removed or the need for it ceases, there are several more functions that still need attention within that jurisdiction (Hooghe \& Marks 2003, p. 236f; Marks \& Hooghe 2004).

The second, Type II, differs on all four characteristics. First, it is constituted by specialized jurisdictions, and each function is dealt with separately. Second, there is no limit to the number of jurisdictions (or levels); rather there can be one for each particular function. Third, since each jurisdiction specializes in particular functions they often overlap geographically. Finally, Type II jurisdictions fluctuate considerably, they may be created to deal with a particular function and as this function is no longer needed they disappear. This makes them potentially much leaner and flexible than Type I, as they can adapt to changes in governance more easily (Hooghe \& Marks 2003, p. 236f; Marks \& Hooghe 2004).

As described by Montin (2007), climate politics are organized according to both Type I and Type II models. By analyzing the goal setting in Sweden, he finds that four levels (international, national, regional, and local) are identified officially, with a myriad of actors, all of which are involved simultaneously in climate change politics. He further recognizes that there are formal institutions and actual institutions involved in this organization. Simply put, formal institutions tend to be more hierarchical and thus organized according to a Type I model. However, the present, territorial organization of governance sometimes opposes effective implementation of climate policy (von Borgstede, Zannakis, \& Lundqvist 2007, p. 77). As shown by Bulkeley and Betsill (2003), Gustavsson, Elander, and Lundmark (2009), and others, more informal constellations in network form has surged to fill a need for lower levels to organize between each other. This organization would fall under the Type II model. Networking, 
nonetheless, does not only occur horizontally, rather there are instances of integration and network behavior also vertically. In these cases the networks are mostly incentivized, promoted, or controlled by higher levels.

\section{Modes of Governance}

There is also a need for tools to categorize mitigation activities. One way of categorizing is by the mode of governance. Schroeder and Bulkeley (2009) and Alber and Kern (2008) suggest four modes of governance that local governments can use to implement climate change mitigating policies. The first is called self-governing and refers to the governments' ability to control its consumption of various products and services (Alber \& Kern 2008, p. 176; Schroeder \& Bulkeley 2009, p. 352). Measures in areas where the government decides on its own consumption is pretty straightforward and is arguably the easiest set of measures to mitigate climate change available on the local level.

The second mode is governing through enabling. This mode is quite broad and refers both to educational and awareness increasing measures, such as education campaigns and promotional activities, and to the facilitation of cooperation between stakeholders in society (Alber \& Kern 2008, p. 176f). Public-private partnerships and the provision of financial incentives from other levels are examples of this (Schroeder \& Bulkeley 2009, p.356).

The third mode is governing by provision. This mode refers to the local governments role in providing services to the public (Alber \& Kern 2008, p. 177f). Municipal governments often hold seats or own shares in local utility companies for, for example, energy, transport, water and waste services. By changing the way these services are provided for, the government can steer and influence the behavior of individuals.

The final mode presented by the authors is governing by regulation. It falls under municipal jurisdiction to regulate certain behaviors. Alber and Kern (2008, p. 178) identify the energy, transport, and construction sectors as areas where local government has the potential to set standards to mitigate climate change.

\section{Sources}

The research related in this paper is based on a combined qualitativequantitative study, using three types of sources: secondary sources in the form of academic material and reports; primary written sources in the form of official government documents; and semi-structured interviews. The interviews were conducted between 2011 and 2012 with government officials and other potential stakeholders. To the extent it is possible, a variety of written material is used to 
add to the description provided in the interviews. Still, inevitably, there is a strong reliance on governmental documents, reports, statistics, and similar data. This paper presents, due to space limits, only parts of a larger study and is concentrated on two case-cities: Stockholm and Gothenburg. The choice of a small- $N$ case study was made in an effort to distinguish more deeply the relationshipbetween local governmentsand other levels of competence. Evidently, this relationship will look differently in all countries, as the institutional arrangements are often dissimilar. The purpose here is, thus, to offer an addition to the theoretical understanding of this issue, rather than to present a replicable model for all institutional environments.

For more details on the full study, the reader may consult Franzén (2012). The written sources used in the part of the study presented here, in addition to the interviews, are Brandt, Fahlberg, \& Johansson (2007), Stockholms stad (2003a; 2003b; 2007a; 2007b; 2010a; 2010b)Göteborgs stad (2005; 2009; 2010; 2011a), and GR (2009).

\section{Climate Change Governance in Stockholm and Gothenburg Introducing Governance in Sweden and the Concept of Competence}

Sweden, although being a unitary state, has a long tradition of decentralized, local governance (Jones 1993, p. 118; Häggroth 2000, p. 12). In comparison with other European countries outside the Nordic region, Swedish municipalities enjoy considerably higher levels of autonomy (Granberg 2008, p. 364). Also Sweden is divided into three basic levels: national, county, and municipal. To these must also be added the EU, which since the Swedish entrance in the union in 1995 has come to play an important role. The autonomy of local government is largely expressed in the 1974 Constitution Act.Local government is also provided jurisdiction through special regulation. In these cases, the national parliament (riksdag) has provided local government with additional competence and responsibility. In addition, there is a complicated web for municipal finance, where local income tax, state grants of different kinds, and the ability to charge for specific services within the municipality is part of the mixture (Häggroth 2000 , p. $27 \mathrm{ff}$ ). At the same time as local government by law enjoys considerable freedom, central government seems to prefer a certain level of control (Kleven et al. 2000, p. 95).

Besides this sophisticated relationship with the national level, local governments in Sweden, have jurisdiction over key areas to climate change mitigation work. According to law, Swedish municipalities have responsibility over education, social welfare, sanitation, health and environmental issues, and urban planning. To these, there is important voluntary provision of services, for example energy provision, which can be akey part of mitigation work. Public transport is the 
responsibility of both the municipality and the county (Finansdepartementet 2012, p. 10).

One concept that needs to be introduced here is competence. Competence in this context means authority in its wide sense, that is: the power over decisionmaking and implementation of a specific measure. The City of Stockholm offers a classification for competence that is useful to categorize the measures in the different Cities and reach a deeper understanding for the organization of the mitigation work (Stockholms stad 2010a, p. 24). Inspired by this classification a scale reaching from high to medium-high, medium-low, and low was created. The factors given by the Stockholm classification moves on three axes: legal authority, finance, and number of actors. The axes of legal authority and finance are quite straightforward and refer to the jurisdiction and financial means available to the local government to act. The number of actors-axis, on the other hand, refers to what extent the local government is depending on other, external actors in order to implement the policy. These might be, for example, private sector, utility companies, civil society organizations, or other local governments. The more actors involved, the lower the competence of the city becomes.

\section{The Actions and Local Government Competence}

Stockholm and Gothenburg are Sweden's largest cities and growth engines in their respective regions. Both cities also suffer from similar problems with traffic congestion. There is a large difference, nonetheless, in industry structure. Heavy industry has largely lost its role in Stockholm's economy, which is now to more than eighty percent represented by the service sector (USKAB 2009). In Gothenburg, the Nordic region's largest harbor is situated within the municipality borders, together with some of the country's most important refineries. Both cities have stated targets for GHG reductions; however, these targets are defined differently. The targets can be seen summarized in Table 1.

Table 1 - Summary of Local Targets for Climate Change Mitigation

\begin{tabular}{|l|l|l|}
\hline \multicolumn{1}{|c|}{ City } & \multicolumn{1}{|c|}{ Short-Term Target* } & \multicolumn{1}{c|}{ Long-Term Target* } \\
\hline Stockholm & 3,0 tons CO2 per capita by 2015. & Fossil fuel free by 2050. \\
\hline Gothenburg & $\begin{array}{l}\text { By 2020, the emissions of carbon } \\
\text { dioxide from the non-active sector have } \\
\text { been reduced with at least 30 \% } \% \\
\text { compared to 1990. }\end{array}$ & $\begin{array}{l}\text { By 2050, Gothenburg has a } \\
\text { sustainable and fair level of emission } \\
\text { of carbon dioxide. }\end{array}$ \\
\hline
\end{tabular}

* Targets were translated into English by author

Developed by author 
The targets in Gothenburg are evidently less precise than the targets in Stockholm, and in the short-term targets the active sector (that is the industry) is not included. The City sees itself as a location of production and hub of communications for the entire country and concentrates in its goals on the more non-active sectors, such as local energy use/production and transports.

The actions undertaken in Stockholm and Gothenburg have been categorized according to three aspects: the $\mathrm{CO}_{2} \mathrm{e}$ reduction achieved, the mode of governance, and the level of competence enjoyed by the local government.

Table 2 - Development of GHG Reducing Actions in Stockholm over Time According to Competence

\begin{tabular}{|c|c|c|c|c|c|c|c|c|c|}
\hline $\begin{array}{c}\text { Competence } \\
\text { over time }\end{array}$ & $\begin{array}{c}\text { Actio } \\
\mathrm{n}\end{array}$ & $\begin{array}{l}98-200 \\
\% \text { of } \\
\text { actio } \\
n\end{array}$ & $\begin{array}{c}\% \text { of } \\
\text { GH } \\
\text { G } \\
\text { red. }\end{array}$ & $\begin{array}{c}\text { Actio } \\
\mathrm{n}\end{array}$ & $\begin{array}{c}\% \text { of } \\
\text { actio } \\
n\end{array}$ & $\begin{array}{c}\% \text { of } \\
\text { GH } \\
\text { G } \\
\text { red. }\end{array}$ & $\begin{array}{c}\text { Actio } \\
\mathrm{n}\end{array}$ & $\begin{array}{l}2010- \\
\% \text { of } \\
\text { actio } \\
\mathrm{n}\end{array}$ & $\begin{array}{c}\% \text { of } \\
\text { GH } \\
\text { G } \\
\text { red. }\end{array}$ \\
\hline \multirow{4}{*}{$\begin{array}{l}\text { High } \\
\text { Medium-high* } \\
\text { Medium-low** } \\
\text { Low }\end{array}$} & 4 & $40 \%$ & $0 \%$ & 11 & $33 \%$ & $10 \%$ & 11 & $58 \%$ & $17 \%$ \\
\hline & 1 & $10 \%$ & $0 \%$ & 8 & $24 \%$ & $11 \%$ & 0 & $0 \%$ & $0 \%$ \\
\hline & 7 & $70 \%$ & $100 \%$ & 7 & $21 \%$ & $67 \%$ & 3 & $16 \%$ & $59 \%$ \\
\hline & 0 & $0 \%$ & $0 \%$ & 7 & $21 \%$ & $12 \%$ & 5 & $26 \%$ & $24 \%$ \\
\hline \multicolumn{4}{|l|}{ ktons/year } & \multicolumn{3}{|r|}{765} & \multicolumn{3}{|r|}{461} \\
\hline
\end{tabular}

* Actions where the City is dependent on finance or cooperation with other actors

** Actions where the main stakeholder is another actor than the City and the City is only partially involved through partial ownership or representation

Developed by author

When it comes to Stockholm, the City has had surprisingly restricted competence over a great part of the GHG reductions, as shown in Table 2. In the early period from 1998 to 2002, almost the totality of the reductions came from measures where the city only was involved through representation or partial ownership - in the public transport authority, SL, and the energy company, Fortum. Nonetheless, there is an increase in the measures owned by the City after the first time period. In the middle period, from 2003 to 2009, 21 percent of the GHG reductions are accounted for in the higher end of the scale. 11 percent of these are dependent on external finance, principally contributions from national programs. In the later period, 2010-2020, the amount of measures where the City enjoys higher competence drops somewhat to 17 percent of the GHG reductions. However, the entirety of these reductions is within the competence of the City, both as it is the main stakeholder, as well as the sole provider of financial means. In all the three periods the amount of measures to which the City has high competence is considerable, but they do not constitute a 
sizeable part of the GHG reductions. Instead, these are small-scale measures, rarely reaching higher than 25 thousand tons $\mathrm{CO}_{2} \mathrm{e}$ per year.

As can be seen in Table 3, the City does use all the instruments available to it and measures falling into the high-competence category use all four modes of governance. What becomes clear, however, is how the absolute bulk of GHG reductions are implemented with medium-low competence - that is, where the main stakeholder is external to the local government - and in provision activities.

\section{Table 3 - Competence According to Mode of Governance}

\begin{tabular}{|c|c|c|c|c|c|}
\hline \multirow{2}{*}{ Competence } & \multicolumn{4}{|c|}{ ktons $\mathrm{CO}_{2} \mathrm{e}$ reduction according to Mode of Governance } & \multirow{2}{*}{$\begin{array}{r}\text { Total ktons } \\
\mathrm{CO}_{2} \mathrm{e}\end{array}$} \\
\hline & Provision & Enabling & Self-governance & Regulation & \\
\hline \multirow{4}{*}{$\begin{array}{l}\text { High } \\
\text { Medium-high* } \\
\text { Medium-low** } \\
\text { Low }\end{array}$} & 34,5 & 44,6 & 36,4 & 45,4 & 160,9 \\
\hline & 2,6 & 44,9 & 40,0 & 0,0 & 87,5 \\
\hline & 1191,1 & 0 & 29,4 & 0,0 & 1220,5 \\
\hline & 10,4 & 20,3 & $660^{* * *}$ & 169,3 & $200,0(860)$ \\
\hline Total ktons $\mathrm{CO}_{2} \mathrm{e}$ & 1238,6 & 109,8 & $105,8(765,8)$ & 214,7 & \\
\hline \multicolumn{6}{|c|}{$\begin{array}{l}* \text { Actions where the City is dependent on finance or cooperation with other actors } \\
* * \text { Actions where the main stakeholder is another actor than the City and the City is only partially } \\
\text { involved through partial ownership or representation } \\
* * * \text { This number reflects a future implementation of CCS, which is highly uncertain. } \\
\text { Developed by author }\end{array}$} \\
\hline
\end{tabular}

In Gothenburg, on the other hand, the local energy company Göteborgs Energi has another owner structure than the counterpart in Stockholm, Fortum, thus Gothenburg enjoys higher competence in several energy/provision-related activities.In contrast to Stockholm and Fortum, Göteborgs Energi is fully owned by the City and politically appointed members constitute the board of directors. This mayhave made it possible for the City to more directly steer the company's activities than in Stockholm, increasing the competence in several of the key actions. However, these activities are often still dependent on external financing, which places them in the medium-high range.

When it comes to transports there are more similaritieswith Stockholm. Gothenburg is also dependent on regional actors for major transport infrastructure activities. The GHG reductions for some of these activities have yet not been calculated and it is difficult to give an exact picture (as done above for Stockholm) over the distribution of reductions according to mode of governance or competence. In addition, several of the activities in transport infrastructure come in a package. This package is mainly competence of the Västra Götalands Region, which would be the equivalent of a county in other parts of Sweden. In the regional cooperation, the City of Gothenburg has representation similarly to Stockholm in its county. There are parts of the package where the City enjoys full competence, for example the parking policy. 
However, there are also parts where the City enjoys little competence, as in the case of congestion charges, where national laws are required and it is the Tax Agency (Skatteverket), which is the only entity entitled to levy a similar tax, and the Swedish Transport Agency (Transportstyrelsen) and the Swedish Transport Administration (Trafikverket) that are in charge of the implementation (Transportstyrelsen 2012). This shows the complexity of climate change mitigation work and how several levels and actors are simultaneously active.

\section{Concluding Discussion}

Two initial points can be made. First of all, actions that affect fundamental provision services in the City, such as energy, heating, public transports, waste handling, are important tools to reduce emissions.

Secondly, the study shows that there are a small number of actions that stand for the bulk of GHG reductions and a large quantity of actions that contribute very little. For example,in Stockholm at each time period described in Table 1 above, between one and three actions stand for more than half of the reduction.

The way local governments are nested into Type- 1 jurisdictions - that is, a hierarchic structure similar to a Russian doll, where one jurisdiction is found inside another and is bound to a geographical space - makes several important areas out of reach for municipal decision-making. These lacunas in local competence affect the way cities can address climate change. Activities that are providing services, which stand for almost the entire GHG reduction in one or two actions, in reality, for the local government, become enabling activities since it stands only as a negotiator with another level or actor, or both.

Thus the competence of the City often inhibits it to take action on its own. Financial, jurisdictional, as well as -although not fully mentioned here organizational constraints offer little leeway for the city to include climate change mitigation completely among its policies. However, the city does enjoy a privileged position as a possible hub for connecting different levels of government, actors in civil society, and local business to create an environment for a more efficient implementation of policies, specific to local circumstances and needs. This governance would be more in the lines of networking, Type-2 governance.

\section{References}

Adger, N. W. (2001) Scales of Governance and Environmental Justice for Adaptation and Mitigation of Climate Change. Journal of International Development, Vol. 13, pp. $921-931$ 
Alber, G. \& Kern, K. (2008) Governing Climate Change in Cities: Modes of Urban Climate Governance in Multi-Level Systems. In OECD Conference Paper Competitive Cities and Climate Change, Milan, Italy 9-10 October

Betsill, M. M. \& Bulkeley, H. (2006) Cities and the Multi-Level Governance of Global Climate Change. Global Governance, Vol. 12, pp. 141-159

Biermann, F. \& Dingwerth, K. (2004) Introduction: Global Environmental Change and the Nation State. Global Environmental Politics, Vol. 4, No. 1, pp. 1-22

Borja, J. \& Castells, M. (1997) Local \& Global: Management of Cities in the Information Age. London: Earthscan Publications Limited

Brandt, N. Fahlberg, K., \& Joahnsson, S. (2007) Uppföljning av àtgärder inom Stockholms stads Handlingsprogram mot växthusgaser. Stockholm: KTH

Bulkeley, H. (2005) Reconfiguring Environmental Governance: Towards a Politics of Scales and Net- works. Political Geography, Vol. 24, No. 8, pp. 875-902

Bulkeley, H. \& Betsill, M. M. (2003) Cities and Climate Change: Urban Sustainability and Global Environmental Governance. London: Routledge

Corfee-Morlot, J., Lamia K-C., Michael G. D., Ian C., Alexis R. \& Teasdale, P. J. (2009), Cities, Climate Change and Multilevel Governance. OECD Environmental Working Papers $N^{\circ} 14$, OECD publishing

Dietz, T., Ostrom, E., \& Stern, P. C. (2003) The Struggle to Govern the Commons. Science, Vol. 302, pp. 1907-1912

Doucet, D. (2007) Urban Meltdown: Cities, Climate Change and Politics as Usual. Gabriola Island, Canda: New Society Publishers

Finansdepartementet (2012) Kommuner och landsting - organisation, verksambet och ekonomi. Stockholm: Finansdepartementet, Regeringskansliet. Available online at: http://www.regeringen.se/sb/d/1906/a/152464 (Accessed on 27 February 2012).

Franzén, M. (2012) Cities and Climate Change: How Can We Understand Local Action? Master's Thesis, Department of Economic History, Stockholm University

GR - Göteborgsregionens Kommunalförbund (2009) K2020: Kollektivtrafikprogram för Göteborgsregionen. Göteborg: Göteborgsregionens Kommunalförbund

Granberg, M. (2004) Redefining the City: Globalisation, Structural Change and Urban Effects. Paper prepared for the City Futures Conference on Globalism and Urban Change, Chicago, United States, 8- 10 July 2004

(2006) Alla talar om vädret: svenska kommuner, klimatförändringar och samverkan. Kommunal ekonomi och politik, Vol. 10, No. 1, pp. 9-35

(2008) Local Governance 'in Swedish'? Globalisation, Local Welfare Government and Beyond. Local Government Studies, Vol. 34, No. 3, pp. 363-377

Gustavsson, E., Elander, I. \& Lundmark, M. (2009) Multi-Level Governance, Networking Cities, and the Geography of Climate-Change Mitigation: Two Swedish Examples. Environment and Planning C: Government and Policy, Vol. 27, pp. $59-74$

Göteborgs stad (2005) Göteborgs energiplan 2005. Göteborg: Göteborgs stad (2009) Miljöanpassat byggande: Göteborg. Göteborg: Fastighetsnämnden i Göteborgs stad 
(2010) Borgmästaravtalet: åtaganden om bållbar lokal energi - Strategier och åtgärder för Göteborgs Stad till 2020. Göteborg: Göteborgs stad

(2011a) Strategi för energieffektivisering i Göteborg Stad till 2014 och 2020. Göteborg: Miljöförvaltningen i Göteborgs stad

Hochstetler, K. \& Viola, E. (2011) Brazil and the Multiscalar Politics of Climate Change. Paper presented at the 2011 Colorado Conference on Earth Systems Governance, Colorado State University, Fort Collins, Colorado, 17-20 May 2011

Hooghe, L. \& Marks, L. (2001) Multi-Level Governance and European Integration. Boston: Rowman \& Littlefield Publishers Inc.

(2003) Unraveling the Central State, but How? Types of Multi-Level Governance. Amer-ican Political Science Review, Vol. 97, No. 2, pp. 233-243

Häggroth, S. (2000) Local Governance: The Case of Sweden. Stockholm: Hjalmarson \& Högberg

Janssen, M. A., Anderies, J. M., Ostrom, E., Tobias, R. \& York, A. (2008) Crafting Local Opportunities to Meet Global Challenges. Notes prepared for The Long Haul: Navigating the Energy Transition to Limit Climate Change, Dunsmuir Lodge, United States, 11-13 August 2008

Jones B. (1993) Sweden. In Chandler, J. A. Local Government in Liberal Democracies: An Introductory Survey. London: Routledge

Kleven, T., Floris, T. S., Granberg, M., Montin, S., Rieper, O. \& Valo, S. I. (2000) Renewal of Local Government in Scandinavia: Effect for Local Politicians. Local Government Studies, Vol. 26, No. 2, pp. 93-116

Kousky, C. \& Schneider, S. H. (2003) Global Climate Policy: Will Cities Lead the Way? Climate Policy, Vol. 3, pp. 359-372

Lefebvre, H. (2003 [1970]) La Révolution Urbaine. Minneapolis: The University of Minnesota Press

Marks, G. \& Hooghe, L. (2004) Contrasting Visions of Multi-Level Governance. In Bache, I. \& Flinders, M. Multi-Level Governance. Oxford: Oxford University Press. Ch. 2, pp. 15-30

Montin, S. (2007) Kommuner och klimatpolitiken - ett exempel på tredje generationens politikområden.Statsvetenskaplig Tidskrift, Vol. 109, No. 1, pp. 37- 57

Osofsky, H. M. \& Levit, J. K. (2008) The Scale of Networks? Local Climate Change Coalitions. ChicagoJournal of International Law, Vol. 8, No. 2, 409-436

Ostrom, E. (2010) Polycentric Systems for Coping with Collective Action and Global EnvironmentalChange. Global Environmental Change, Vol. 20, pp. 550-557

Otto-Zimmermann, K. (2011) Embarking on Global Environmental Governance: Thoughts on the Inclusion of Local Governments and Other Stakeholders in Safeguarding the Global Environment. ICLEI Paper 2011-1. Bonn, Germany: ICLEI

Parker, S. (2004) Urban Theory and the Urban Experience. New York: Routledge

Rabe, B. G. (2004) Beyond Kyoto: Designing Policies to Reduce Greenhouse Gas Emissions in Federated Governance Systems. Paper prepared for the Smart Practices Toward Innovation in Public Manage- ment Conference of the International 
Political Science Association Research Committee on the Struc-ture and Organization of Government, Vancouver, Canada, June 2004

- (2007) Beyond Kyoto: Climate Change Policy in Multi-Level Governance Systems. Governance: An International Journal of Policy, Vol. 20, No. 3, pp. 423-444

Rees, W. \& Wackernagel, M. (1996) Urban Ecological Footprints: Why Cities Cannot be

Sustainable - and why They are Key to Sustainability. Environmental Impact Assessment Review, Vol. 16, pp. 223- 248

Rose, D. D. (1973) National and Local Forces in State Politics: The Implication of Multi-Level Policy Analysis. The American Political Science Review, Vol. 67, No. 4, pp. 1162-1173

Schroeder, H. \& Bulkeley, H. (2009) Global Cities and the Governance of Climate Change: What is the Role of Law in Cities? Fordham Urban Law Journal, Vol. XXXVI, No. 2, pp. 313-359

Stockholms stad (2003a) Stockholm's Action Programme Against Greenhouse Gas Emissions. Stockholm: Stockholms stad

(2003b) Utlåtande 2003:38 RVIII+I (Handlingsprogram mot växthusgaser: Ansökan om statligt stöd forr klimatinvesteringar (KLIMP) inom Stockholms stad 2003-2006). Stockholm: Stockholms stad

. (2007a) Minskade utsläpp av växthusgaser $i$ Stockholms stad àr 2015. Stockholm: Miljöförvaltningen

- (2007b) Stockholms handlingsprogram mot växthusgaser 2000-2005: Uppföljning. Stockholm: Miljöförvaltningen Stockholms stad

- (2010a) Stockholms àtgärdsplan för klimat och energi 2010-2020. Stockholm: Miljöförvaltningen Stockholms stad

(2010b) Slutrapport av Stockholms stads klimatinvesteringsprogram 2006-2010. Stockholm: Stockholms stad

Transportstyrelsen (2012) (online) Trängselskatt i Göteborg: Ansvar och Kontakt. Available at: http://www.transportstyrelsen.se/sv/Vag/Trangselskatt/Trangselskatt-igoteborg/Fragor--svar/Fragor-svar-om-trangselskatt-i-goteborg111111/ (Accessed on 30 March 2012)

USKAB - Statistik om Stockholm (2009) (online) Förvärusarbetande befolkning efter näringsgren och kön 2009. Available at: http://www.usk.stockholm.se/tabellverktyg/tv.aspx?t=a71 (Accessed on 4 March 2012)

Von Borgstede, C., Zannakis, M., \& Lundqvist, L.J. (2007) Organizational Culture, Professional Norms and Local Implementation of National Climate Policy. In Lunqvist, L.J. \& Biel, A. (eds.) From Kyoto to the Town Hall: Making International and National Climate Policy Work at the Local Level. London: Earthscan. Ch. 6, pp. 77-92

Weber, M. (1958) The Protestant Ethic and the Spirit of Capitalism. New York: Scribners Wilbanks, T. J. \& Kates, R. W. (1999) Global Change in Local Places: How Scale Matters. ClimaticChange, Vol. 43, pp. 601-628 